\title{
Stock Price Synchronicity and Material Sustainability Information
}

\section{Citation}

Grewal, Jody, Clarissa Hauptmann, and George Serafeim. "Stock Price Synchronicity and Material Sustainability Information." Harvard Business School Working Paper, No. 17-098, May 2017.

\section{Permanent link}

http://nrs.harvard.edu/urn-3:HUL.InstRepos:33110114

\section{Terms of Use}

This article was downloaded from Harvard University's DASH repository, and is made available under the terms and conditions applicable to Open Access Policy Articles, as set forth at http:// nrs.harvard.edu/urn-3:HUL.InstRepos:dash.current.terms-of-use\#OAP

\section{Share Your Story}

The Harvard community has made this article openly available.

Please share how this access benefits you. Submit a story.

Accessibility 


\section{Stock Price Synchronicity and Material Sustainability Information}

Jody Grewal

Clarissa Hauptmann

George Serafeim

Working Paper 17-098 


\title{
Stock Price Synchronicity and Material Sustainability Information
}

\author{
Jody Grewal
}

Harvard Business School

Clarissa Hauptmann

Maastricht University

George Serafeim

Harvard Business School

Working Paper 17-098 


\title{
Stock Price Synchronicity and Material Sustainability Information
}

\author{
Jody Grewal, Clarissa Hauptmann and George Serafeim*
}

$2^{\text {nd }}$ of May, 2017

\begin{abstract}
We examine if, and under what conditions, disclosure of sustainability information identified as investor relevant by market-driven innovations in accounting standard-setting, is associated with stock prices reflecting more firm-specific information and thereby lower synchronicity with market and industry returns. We find that firms voluntarily disclosing more sustainability information, identified as material by the Sustainability Accounting Standards Board (SASB), have lower stock price synchronicity. This result is stronger for firms with higher exposure to sustainability issues, institutional and socially responsible investment fund ownership and coverage from analysts with less firm-specific experience and lower portfolio complexity. Moreover, we find intra-industry information transfers to firms with low sustainability disclosure within industries with high sustainability disclosure. We also document that sustainability information not identified by the accounting standard setting process is not associated with stock price synchronicity.
\end{abstract}

Keywords: voluntary disclosure, accounting standards, sustainability, nonfinancial information, corporate social responsibility, stock price synchronicity

\footnotetext{
* Jody Grewal is a doctoral candidate at Harvard Business School. Clarissa Hauptmann is a doctoral candidate at Maastricht University. George Serafeim is the Jakurski Family Associate Professor of Business Administration. We thank David Freiberg for excellent research assistance. George Serafeim acknowledges financial support from the Division of Faculty and Research Development of Harvard Business School. George Serafeim has served on the Standards Council of SASB. Contact email: gserafeim@hbs.edu.
} 


\section{INTRODUCTION}

The number of companies disclosing and investors using sustainability information has grown exponentially over the past few years. While only a few companies disclosed such information in the early 2000s, it has now become common practice for companies to communicate the relevance of such information for their business strategy and operations. However, in the United States, but also internationally, such disclosures are not yet guided by a set of accounting standards that define investor relevant disclosure requirements. This stands in contrast to financial reporting, which is largely driven by requirements set in financial accounting standards. The formation of financial accounting standards is considered an important element of the development of capital markets and the efficient allocation of capital in an economy (Levitt 1998; Healy and Palepu 2000) and a long line of research examines the effect of standards on economic outcomes (see for example, Barth, Landsman and Lang 2008; Naughton, Petacchi and Weber 2015; Bratten, Choudhary and Schipper 2013).

Recent survey findings suggest that a large number of market participants consider the development of standards to account for firms' environmental and social inputs and outcomes, such as energy and water consumption, employee and workplace practices, product safety, and access to affordable products for customers, is important, as these metrics constitute relevant information to understanding the risks and opportunities that an organization faces (Amel-Zadeh and Serafeim 2017). As a result, standards have emerged that companies can voluntarily adopt to disclose investor relevant sustainability information. While it is early to judge the potential market adoption of the standards and the effects on markets and organizations, publicly listed companies, such as JetBlue and Kilroy Realty, have decided to adopt the standards thereby generating a need for systematic research on the characteristics of the information identified in the standards. To address this void, we examine whether firms that voluntarily disclosed information later identified in the standards as investor relevant, exhibited lower stock price synchronicity,

consistent with voluntary disclosure of sustainability information enabling the incorporation of firmspecific information in stock prices. 
Our research setting is the accounting standards developed by the Sustainability Accounting Standards Board (SASB). SASB adopts an investor viewpoint and has identified sustainability metrics that are likely to be of relevance to investors. Large asset managers, such as BlackRock, Capital Group, and State Street, participate in the investor advisory group of SASB, while the board of directors comprise a group of individuals with deep accounting and capital markets expertise, including former accounting standards setters from the Financial Accounting Standards Board (FASB) and SEC commissioners. According to SASB, specific sustainability issues are more or less investment relevant depending on a company's industry and, as a result, accounting standards are industry-specific. To construct a measure of material sustainability information for each firm, we create a disclosure score using Bloomberg data items that have been mapped to the SASB issues for each industry. Therefore, the data items that comprise the disclosure score are industry-specific and each firm scores according to its disclosure practices in relation to metrics deemed financially material for that industry.

Our measure of firm-specific information in stock prices is the measure of stock price synchronicity that has been extensively used in prior research (Wurgler 2000; Durnev, Morck and Yeung 2004; Piotroski and Roulstone 2004; Crawford, Roulstone and So 2012). Using sustainability data between 2007 and 2014 for a sample of 1,333 US-listed companies, we find a negative and significant association between our measure of material sustainability information and stock price synchronicity. This association is not mediated when we control for whether the firm issues a sustainability report. In addition, we find that the association between synchronicity and the presence of a sustainability report is insignificant. In additional analyses, we document that sustainability disclosures not identified by the standards and compliance with sustainability disclosure standards that do not cater to investors are also not correlated with stock price synchronicity.

We find that the documented association between material sustainability information and stock price synchronicity is moderated by several variables. These moderating effects provide new insights into the firm and capital market characteristics that enable the incorporation of sustainability information in stock prices, while increasing our confidence that the sustainability information rather than a correlated 
omitted variable drives the association with stock price synchronicity. Moreover, these results increase our confidence that in our setting, the stock price synchronicity measure reflects incorporation of firm-specific news rather than noise in stock prices (Li, Rajgopal, and Venkatachalam 2014). Two key sets of variables are included as moderators: firm characteristics and capital market participant characteristics.

On the firm side, we expect the negative relation between stock price synchronicity and material sustainability information to be stronger for firms for which sustainability issues are more important. We construct two proxies for the importance of sustainability issues. The first is a measure of a company's exposure to sustainability issues using data from Morgan Stanley Capital International (MSCI). While SASB defines sustainability issues that are material at the industry level, different companies within the same industry have varying degrees of exposure to the same issues. For example, an apparel company with a long supply chain in Bangladesh is more exposed to human rights issues compared to an apparel company with a supply chain in Canada. Similarly, a real estate company with properties in Miami Beach is more exposed to climate change and rising sea levels compared to a real estate company with properties in a noncoastal US city. The second proxy is a measure from Thomson Reuters ASSET4 of the integration of sustainability issues in a company's business strategy and operations. For example, while a consumer goods company might have made access to healthier products core to its business, transitioning their product portfolio away from unhealthy options and creating a strong brand around this issue, another consumer goods company might have introduced additional options for consumers while keeping a balanced portfolio. The former company develops a strong identification of the entire company and brand with the focal sustainability issues, while the latter does not. We find that both variables significantly moderate the association between sustainability information and stock price synchronicity.

On the capital markets side, we expect that investors with higher information processing capabilities will be more effective at incorporating material sustainability information in stock prices. Our first measure is the percentage of institutional investors holding the outstanding shares of each company, as institutional investors are more likely to be able to process the valuation implications of new types of information, such as sustainability information, compared to retail investors. The second proxy is the 
percentage of shares outstanding held by funds labeled as socially responsible. While these funds are not the only funds using sustainability information, their long history of using the information might increase their processing ability. We find that both measures significantly moderate the association between sustainability information and stock price synchronicity. We also document that firms covered by analysts with higher portfolio complexity (i.e. analysts that cover more firms) have a weaker association between sustainability information and stock price synchronicity. This is consistent with analysts that have higher processing costs, due to higher workload, being less capable of processing sustainability information. Finally, we find that firms covered by analysts with more firm-specific experience have a weaker association between sustainability information and stock price synchronicity. Although one might expect that more experienced analysts would be able to process sustainability information more effectively, our results suggest that lack of experience and disclosure could be complements in that more disclosure is needed for less experienced analysts to be able to process the information.

We also examine the presence of intra-industry information transfers (Foster 1981; Gleason et al. 2008 ) in the context of sustainability information. If information transfers exist, we expect that stock returns of firms that disclose little information about their material sustainability issues will exhibit higher comovement with industry returns, if they belong to an industry where companies' disclosure levels are high. In contrast, we expect no effect on co-movements with industry returns for firms that disclose little information but belong to industries where on average companies' disclosure levels are low. We measure the level of industry information in stock returns as the difference between the explanatory power of market and industry returns versus only market returns, following Piotroski and Roulstone (2004). The higher this difference, the more a firm's stock returns contain industry-level information. We find strong evidence that, within the whole sample, firms with low sustainability disclosure exhibit high industry-level synchronicity, and that this result is driven only by firms in industries with rich information environments (i.e. aboveaverage industry level sustainability disclosure scores).

We conduct a series of robustness tests to assess the validity of our results, including assessing the association between sustainability disclosures not identified by the accounting standards and synchronicity, 
as well as controlling for earnings quality proxies. Moreover, following the recommendations of Li et al. (2014), we conduct additional analyses to examine whether the association with stock price synchronicity is indicative of news or noise in stock prices. Li et al. (2014) recommend controlling for beta in regressions that use stock price synchronicity as the dependent variable to assess whether the documented relation changes sign or disappears. In our case, we find that there is still a negative and significant association when controlling for both market and industry beta suggesting the association between sustainability disclosures and both synchronicity and idiosyncratic volatility yields consistent results.

This study contributes to four different streams of literature. First, an emerging literature examines the development of accounting standards for disclosure of sustainability information (Khan, Serafeim and Yoon 2016). We build on this line of work to examine how firm disclosures around material sustainability issues are associated with firm-specific information being reflected in market prices. In contrast to Khan et al. (2016), we examine variation in firms' disclosure practices rather than ratings of firms' sustainability performance as our independent variable of interest. ${ }^{1}$ Disclosure and ratings of performance are different theoretical constructs, as data providers interpret a wide array of information to evaluate a company's performance, but are also empirically distinct, as evidenced by their low (albeit positive) correlation. ${ }^{2}$ In addition, Khan et al. (2016) focus on implications for future market and accounting returns, whereas we focus on implications for the level of firm, industry and market information in stock prices. Our results suggest that firms with higher material sustainability disclosures have stock returns that exhibit lower comovement with market and industry returns, consistent with stock prices moving more because of firmspecific information.

Moreover, we theoretically motivate and empirically examine the conditions under which material sustainability disclosures are most effective in the price discovery process. We document that the

\footnotetext{
${ }^{1}$ Khan et al. (2016) measure sustainability outcomes such as environmental performance (e.g. level and intensity of greenhouse gas emissions), social performance (e.g. employee satisfaction and human rights scandals) and governance performance (e.g. corruption charges), whereas we measure the level of sustainability disclosure (e.g. transparency around emissions, employment practices, human rights policies, and anti-corruption metrics).

${ }^{2}$ The correlation between our disclosure score and the performance rating used in Khan et al. (2016) is approximately 0.1 . Moreover, controlling for their rating in our models does not change any of our inferences.
} 
association between return synchronicity and material sustainability disclosure is a function of a company's competitive positioning and strategy as well as its ownership base, building on a literature that examines the role of strategy and ownership base on the association between voluntary disclosure and capital market outcomes (Healy and Palepu 2000; Bushee and Miller 2012). Relatedly, we contribute to a literature that documents the influence of sustainability disclosures and ratings on analyst recommendations (Ioannou and Serafeim 2015) and forecasts (Dhaliwal et al. 2012). We find that portfolio complexity and analyst experience moderate the relation between sustainability information and synchronicity, highlighting the role of sell-side analysts in intermediating the price discovery process.

Our paper also contributes to a literature that seeks to understand innovations in accounting practices because of standards developed by market forces rather than regulatory forces (Allee and Yohn 2009; Serafeim 2011). Our results build on this literature and suggest that market forces, in our case a focal NGO with the participation of companies, investors and information intermediaries, could develop accounting standards that reflect investor relevant firm-specific information, complementing the regulatory process through which financial accounting standards have been developed.

Finally, our paper makes a contribution to a literature on intra-industry information transfers of regulated financial information. In contrast to the prior literature that examines intra-industry information transfers whereby an idiosyncratic event that affects the short-window stock price of one firm also affects the contemporaneous short-window stock price of another firm in the same industry (Foster, 1981; Gleason et al., 2008) or that documents cross-firm stock return predictability as a function of accounting quality (Chen et al. 2017) we document significantly higher industry-level synchronicity for firms that have low levels of sustainability information disclosure but are members of industries with relatively high levels of sustainability information disclosure.

\section{MOTIVATION AND LITERATURE REVIEW}

Reporting of sustainability information increased exponentially over the past two decades. The number of companies measuring and reporting environmental (i.e. carbon emissions, water consumption, waste 
generation, etc.), social (i.e. employee, product, customer related, etc.), and governance (i.e. political lobbying, anticorruption, board diversity, etc.) data, collectively ESG data, grew significantly. While fewer than 20 companies disclosed ESG data in the early 1990s, the number of companies issuing sustainability or integrated reports had increased to nearly 9,000 by 2016.

Investor interest in ESG data also grew rapidly. Signatories to the UN Principles for Responsible Investment (PRI), launched in 2006, commit to incorporate ESG issues into their investment analysis and ownership policies and practices. As of 2016, the principles had about 1,400 signatories with total assets under management of about $\$ 60$ trillion. $^{3}$ As a further sign of the institutionalization of ESG data, Bloomberg terminals integrated ESG data in 2010, dramatically increasing the diffusion of ESG information. As of 2016, more than 100 rating agencies provided ESG data, including large data providers such as Thomson Reuters and MSCI.

With this increasing investor interest in ESG data, researchers began exploring its decision usefulness from an investment perspective (e.g. Dhaliwal et al. 2011; Cheng et al. 2014; Grewal et al. 2017). ${ }^{4}$ Although an increasing number of investors have committed to incorporate ESG data in their investment decisions, investors view the lack of reporting standards for material sustainability information as the major impediment for using the data (Amel-Zadeh and Serafeim 2017). According to a recent study that surveyed senior investment professionals from organizations representing $43 \%$ of institutional assets under management, the lack of reporting standards for material sustainability information leads to a lack of comparability of reported information across firms and time, increases costs of gathering and analyzing ESG information, and increases the probability of general and boilerplate disclosures (Amel-Zadeh and Serafeim 2017). All these factors limit investors' ability to use ESG information in investment decisions.

\footnotetext{
${ }^{3}$ United Nations Principles for Responsible Investment, http://www.unpri.org/signatories/signatories/.

${ }^{4}$ These studies document that voluntary disclosure of ESG leads to a reduction in the firm's cost of capital, while attracting dedicated institutional investors and analyst coverage (Dhaliwal et al. 2011); that firms with better ESG performance face significantly lower capital constraints (Cheng et al. 2014); and that stock price reactions to mandated ESG disclosure regulation vary predictably based on ex-ante ESG performance (Grewal et al. 2017).
} 
To fill this reporting void, SASB has developed industry-specific reporting standards for financially material sustainability information. SASB uses the SEC definition of materiality as interpreted by the U.S. Supreme Court. ${ }^{5}$ The Public Company Accounting Oversight Board (PCAOB) also refers to the U.S. Supreme Court interpretation of securities laws in its materiality guidance, which defines material information as presenting a substantial likelihood that the disclosure of the omitted fact would have been viewed by the reasonable investor as having significantly altered the total mix of information made available. Like the PCAOB, SASB defines material information as information that represents a substantial likelihood that its disclosure will be viewed by the reasonable investor as significantly altering the total mix of information made available.

Despite the objectives of SASB's reporting standards, we lack evidence about whether the standards indeed provide investors with useful, firm-specific information, and whether investors integrate this information into their valuation of firms that disclose even prior to the development of the standards. Analogous to studies that examine how new accounting standards affect capital market outcomes (e.g. Beatty et al. 1996; Cornett et al. 1996; Dechow et al. 1996) as well as studies examining the value relevance of specific accounting line items over time (e.g. Collins et al. 1997; Francis and Shipper 1999; Barth et al. 2017) we evaluate market-driven innovations in sustainability reporting, due to their possible influence on voluntary disclosure practices and standard setters. Specifically, there may be wide-spread market adoption of SASB across firms and, if the SEC were to mandate sustainability reporting, it could prescribe SASB standards. Moreover, prior research has documented the influence of political and professional characteristics of standard setters on accounting standards (e.g. Allen and Ramanna, 2012; Ramanna, 2008). Given the lengthy, negotiated and multi-stakeholder process that SASB standards evolved from - including the input and involvement of hundreds of companies - evaluating SASB standards is critical given the uncertainty surrounding whether SASB achieved its objective of developing metrics that provide value-

\footnotetext{
${ }^{5}$ TSC Industries v. Northway, Inc., 426 U.S. 438, 449 (1976). See also Basic, Inc. v. Levinson, 485 U.S. 224 (1988).
} 
relevant firm-specific information, as opposed to being influenced by the objective functions of participants in the standard-setting process.

We view the inquiry in this paper as a step towards understanding whether SASB standards could mitigate the impediments to the use of ESG data in investment decisions. In other words, if SASB standards do not capture value-relevant, firm-specific information that is incorporated in stock prices, it is unlikely that the standards will have a significant effect on the use of ESG information by investors. This is because even if SASB standards increase comparability, timeliness and specificity of the disclosed sustainability information in the future, this information will still lack relevance. Moreover, our tests allow us to assess whether capital markets incorporate this information before the development and release of standards that could raise the comparability, timeliness and specificity of information. Therefore, our results could provide a baseline for evaluating the effect of these standards on future disclosure and capital market outcomes.

\section{DATA AND SAMPLE}

\subsection{Materiality Data}

Our data collection is driven by the availability of materiality guidance from SASB, which is an independent 501(c)3 non-profit whose mission is to develop and disseminate sustainability accounting standards that help publicly-listed corporations disclose material factors in compliance with SEC requirements. SASB standards are designed for the disclosure of material sustainability issues in mandatory SEC filings, such as the Form 10-K and 20-F. SASB is accredited to establish sustainability accounting standards by the American National Standards Institute (ANSI), and such accreditation is intended to signify that SASB's procedures to develop sustainability accounting standards meet the Institute's requirements for openness, balance, consensus, and due process. SASB's board comprises a mix of regulators, academics, lawyers, and investors, including two former Chairwomen of the SEC and a former Chairman of the FASB.

SASB adopts an investor viewpoint and, as a result, a topic might be classified as immaterial from an investor standpoint although such a topic could be important for other stakeholders. The investor focus of SASB is different from that of other organizations such as the Global Reporting Initiative (GRI), which 
has a multi-stakeholder focus. In a joint op-ed, the Chief Executives of GRI and SASB explained how the two are complements rather than substitutes. They suggest that "rather than being in competition, GRI and SASB are designed to fulfill different purposes for different audiences... The GRI standards are designed to provide information to a wide variety of stakeholders and consequently, include a very broad array of topics. SASB's are designed to provide information to investors and consequently, focus on the subset of sustainability issues that are financially material."

SASB's standards are developed via a multi-stakeholder process consisting of research supported by Bloomberg technology, data and analytical tools; balanced, multi-stakeholder industry working groups; a public comment period; and review by an independent Standards Council comprised of experts in standards development, securities law, environmental law, metrics and accounting. ${ }^{7}$ SASB convenes industry working groups-consisting of $1 / 3$ corporations, $1 / 3$ market participants, and $1 / 3$ other stakeholders - to provide feedback on SASB's draft sustainability accounting standards. More than 3,000 experts representing more than $\$ 30$ trillion in assets under management and $\$ 15$ trillion in company market capitalization participated in SASB's industry working groups between 2013 and 2016. Importantly, although the standards include a crowdsourcing of industry expert opinions, a scanning of regulated fillings for mentions of different sustainability issues and documentation of cases of impacts on revenues, costs, assets and liabilities, the standard setting process involves no large scale quantitative analysis. Thereby, there is a need for examining the characteristics of these standards and their association with market outcomes.

\subsection{Sustainability Data}

We retrieve data on sustainability disclosure practices from Bloomberg. Bloomberg is the leading source of corporate and financial data on public companies. Bloomberg tracks more than 300 different metrics, covering all aspects of ESG, from political donations to number of environmental spills. ${ }^{8}$ Bloomberg has

\footnotetext{
${ }^{6}$ https://www.greenbiz.com/article/how-approach-corporate-sustainability-reporting-2017

${ }^{7}$ See www.sasb.org

${ }^{8}$ See Framework, Behind the Terminal: Understanding the Bloomberg ESG Numbers, www.framework-llc.co m/wp-content/uploads/2016/01/Bloomberg-ESG-Infographic.pdf
} 
recently integrated a transparent mapping of its ESG disclosure metrics to SASB reporting standards. Given that SASB standards differ across industries, we manually collected for each industry all Bloomberg ESG data items that were mapped to SASB topics. We then constructed disclosure scores by taking into account these industry-specific Bloomberg ESG data items.

We compute the material SASB ESG disclosure score for each firm-year combination (MaterialDisc) as the ratio of number of disclosed SASB ESG metrics to total number of material metrics mandated by SASB and available in Bloomberg. We note that not all of SASB's metrics have corresponding Bloomberg ESG metrics. For example, in the Automobiles industry, SASB has proposed "Average recyclability of vehicles sold, by weight" as a material sustainability metric, but Bloomberg does not collect data pertaining to this metric. Data coverage is different for different industries. This is by construction, as SASB standards are industry specific. For the different sectors, we document on average SASB data coverage of $80 \%$ for Renewables, $78 \%$ for Non-Renewables, $75 \%$ for Transportation, $61 \%$ for Consumption, $61 \%$ for Resource Transformation, 54\% for Technology \& Communications, 52\% for Services, and 45\% for Health Care. While incomplete coverage could create noise in our estimates thereby biasing them towards zero, it is not clear that it will introduce bias in a positive or negative direction. Our estimates are within a SICS industry and therefore differential data coverage across SICS industries should not affect our results. Moreover, it is unlikely that firms are disclosing a significant amount of SASB metrics that are not available in Bloomberg. Per our discussion with an ESG analyst at Bloomberg, the reason why Bloomberg does not collect data points for all of SASB's metrics is because some SASB metrics constitute innovations in sustainability reporting and are not yet being disclosed by firms. Therefore, we view the relative scores of each company within its industry as a fairly accurate rating of its disclosure practices. ${ }^{9}$ We observe that the SASB metrics not covered by Bloomberg are more granular - but very similar in scope - as other SASB metrics that are covered by Bloomberg. For example, in Oil \& Gas, "Gross global Scope 1 emissions" is a SASB metric

\footnotetext{
${ }^{9}$ It could, however, be the case that only the SASB metrics available in Bloomberg are financially material, while the ones that are not available (and that firms do not disclose) are immaterial. This would mean that our inferences are not generalizable to all SASB disclosures.
} 
covered by Bloomberg, while "Global Scope 1 emissions from (1) combustion, (2) flared hydrocarbons, (3) process emissions, (4) directly vented releases, and (4) fugitive emissions" is a SASB metric not covered by Bloomberg. Clearly, the second metric is much more detailed than the first, while they both relate to the same disclosure topic (greenhouse gas emissions) that is financially relevant in this industry.

As SASB does not recommend weights for metrics within an industry, we adjust for double counting of metrics that fall into several topics. For example, within the SASB Sustainable Industry Classification System (SICS) industry "Containers and Packaging", the metric "Human Rights Policy" belongs to two disclosure topics: "Security, Human Rights, and Rights of Indigenous Peoples" and "Community Relations". For our total disclosure score, we only account for "Human Rights Policy" once. Our resulting sustainability disclosure ratio reflects material ESG disclosure according to SASB standards and can range from 0 to 100 percent.

\subsection{Measurement of Stock Return Synchronicity}

A growing literature in both accounting and finance examines the relation between firm-specific variation in stock returns and several aspects of the firm's information or governance environment (e.g. Wurgler, 2000; Durnev et al. 2004; Piotroski et al. 2004; Ferreira et al. 2011; Crawford et al. 2012). These studies proxy for the mix of firm-specific and industry- and market-wide information available about the firm using stock return synchronicity (measured as the $\mathrm{R}^{2}$ value from a regression of firm returns on market and industry returns) where lower $\mathrm{R}^{2}$ reflects stock prices with greater firm-specific information. Therefore, in this paper, we assess whether firms that voluntarily disclose more information, as later prescribed by SASB standards, have lower stock price synchronicity.

We compute stock return synchronicity consistent with previous literature (Roll 1988; Piotroski and Roulstone 2004; Crawford et al. 2012; Li et al. 2014). We collect daily firm stock returns, valueweighted industry returns, and market returns for our sample from CRSP. We winsorize the returns at the 1 and 99 level to remove potential outliers. Following Crawford et al. (2012) we require a minimum of 50 daily observations. We exclude firm-year combinations that have less than 12 trading days for each month, as in Li et al. (2014). For each year, we then estimate firm-specific regressions using market and industry 
returns. We extract the $\mathrm{R}^{2}$ from each of these regressions to compute firm-year synchronicity, defined as follows:

$$
\text { Synchronicity }_{i, t}=\log \left(\frac{R^{2}}{1-R^{2}}\right)
$$

A higher synchronicity value indicates a stronger explanatory power of industry and market returns on firm returns. Conversely, lower synchronicity value reflects lower stock co-movements with industry and market, revealing a higher firm-specific information content of stock returns.

\subsection{Sample Selection}

We begin our data collection process by identifying firms included in the Bloomberg ESG coverage index from 2007 to 2014, which encompasses 9,064 firms. The Bloomberg ESG coverage index includes large and liquid stocks of interest to institutional investors and represents more than $90 \%$ of the total global market capitalization of all equity stocks. Table 1 shows how we arrive at our final sample of firm-year observations. 1,662 firms drop due to missing sustainability disclosure information. As SASB standards are tailored toward companies traded on U.S. exchanges, we exclude non-US listed firms, reducing our sample to 2,365 unique US firms. Following prior literature in synchronicity, we remove financial institutions and utility companies from our sample, leaving us with 1,802 firms. ${ }^{10}$ We collect financial information for the remaining firms from Bloomberg. 469 firms are missing all required financial information and information such as insider trading, leaving us with a final sample of 1,333 unique US companies. This translates into 10,664 firm-year observations over our time period of eight years. Required financial information for 257 firm-year observations is missing, resulting in our final sample comprising 10,407 observations. This sample represents about $56 \%$ of the market capitalization value of US firms and more than $80 \%$ of the market capitalization of US firms, excluding financial institutions and utilities, in Bloomberg's ESG coverage index.

\footnotetext{
${ }^{10}$ We note that stock returns of financial institutions in our period of study are heavily influenced by the financial crisis.
} 
Table 2 presents the frequency distributions of observations in our sample. In Panel A, we provide an overview of the distribution across years. All years have an approximately equal number of observations. In Panel B, we show the distribution across industries. Industry is defined according to SASB's Sustainable Industry Classification System (SICS), which categorizes companies not only based on their sources of revenue, as typically is the case, but also considers intangibles such as shared resource intensity, and sustainability risks and opportunities. ${ }^{11}$ Our sample covers 62 industries in 8 major SICS sectors: Health Care, Technology \& Communications, Non-renewable Resources, Transportation, Services, Resource Transformation, Consumption, and Renewable Resources \& Alternative Energy. The table reveals that our sample is not heavily tilted toward any specific industry, with the most frequently represented industry being "Industrial Machinery \& Goods", comprising 7\% of the sample.

\section{RESULTS}

\subsection{Summary Statistics}

Table 3, Panel A shows the summary statistics for the variables we employ in this study. Our synchronicity measure has a mean of -0.52 and standard deviation of 1.15 , comparable to Piotroski and Roulstone (2004). A negative average synchronicity measure is representative of the existing literature and reveals that on average firm-specific variation accounts for more than half of the variation in stock returns. We find that material sustainability disclosure according to SASB standards (MaterialDisc) is on average $17.2 \%$ with a standard deviation of similar magnitude, indicating considerable variation in disclosure scores in our data. Following the literature, we account for potential correlated omitted factors with an array of control variables. Firm size is measured as the natural logarithm of market value of equity (MarketCap). GRI compliance is an indicator variable that equals one if the firm is following GRI reporting guidelines; it is zero otherwise (GRICompl). In our sample, approximately $8.3 \%$ of firms are GRI compliant. In a similar

\footnotetext{
${ }^{11}$ See www.sasb.org/sics
} 
manner, we report that $18.3 \%$ of our sample provides a separate sustainability report (SustReport). ${ }^{12} \mathrm{We}$ find that on average $76.8 \%$ of the shares are held by institutional investors (InstOwn) within our sample. Further, we account for analyst forecast revisions measured as the natural logarithm of number of forecast revisions (AnalystRev). Our measure is very similar to Piotroski and Roulstone (2004), who advocate the consideration of analyst revisions as relevant factors to the information environment and in particular synchronicity. Additionally, we use the price to book ratio $(M T B)$, standard deviation of return on assets (StdDevROA), and insider trading (InsiderTrades), measured as the natural logarithm of the absolute value of net trading by insiders scaled by annual trading volume. Our summary statistics are all broadly in line with the existing literature, supporting the representativeness of our sample for the US market. Panel B shows the univariate pairwise correlations between our variables. The highest correlation at 0.64 is between the GRI compliance and sustainability report indicator variables. This is expected, as firms that are GRI compliant also issue a sustainability report. We note that correlations between our synchronicity measure and the control variables are consistent with prior literature (e.g. Piotroski and Roulstone 2004; Crawford et al. 2012; Peterson et al. 2015).

\subsection{Material Sustainability Information and Stock Price Synchronicity}

We examine the relevance of SASB accounting standards for sustainability disclosure using a multivariate regression model. We regress one-year ahead stock price synchronicity on material sustainability disclosure according to SASB standards and relevant control variables. The lag ensures that the sustainability information is disseminated in the market. Our regression model is set up as follows ${ }^{13}$ :

\footnotetext{
12 Dhaliwal et al. (2011) use a sample of U.S. firms from 1993 to 2007 and document that $9.14 \%$ of their sample provides a separate sustainability report. Given our sample period of 2007 to 2014 and the significant increase in ESG interest during this period our percentage is higher.

${ }^{13}$ We note that within firm variation of MaterialDisc is low, and as such, we do not model intertemporal comparisons.
} 
Synchronicity $y_{i, t+1}$

$$
\begin{aligned}
& =\alpha_{0}+\beta_{1} \text { material ESG Disclosure }_{i, t}+\beta_{2} \ln \left(M E_{i, t}\right)+\beta_{3} \text { InstOwn }_{i, t} \\
& +\beta_{4} \ln \left(\text { Nrev }_{i, t}\right)+\beta_{5} \text { Price to Book }_{i, t}+\beta_{6} S D\left(R O A_{i, t}\right)+\beta_{7} \ln \left(\text { InsiderTrade }_{i, t}\right) \\
& +\sum_{k=1}^{62} \gamma_{k} \text { Industry }_{i, t}+\sum_{l=1}^{8} \delta_{l} \text { year }_{i, t}+\varepsilon_{i, t}
\end{aligned}
$$

The results, presented in Table 4, reveal that material sustainability disclosure according to SASB standards is negatively associated with stock price synchronicity. Column (1) shows the baseline result. Material sustainability disclosure produces a statistically significant coefficient of -0.51 . Economically, this result indicates that an increase in material ESG disclosure by one standard deviation, i.e. 0.18 units, translates into a decrease in synchronicity of 0.09 , or approximately $8 \%$ of the standard deviation of synchronicity. To ensure that this result is driven by material ESG disclosures identified by the SASB standard setting process, and not by general sustainability disclosure, we control for GRI compliance in column (2) and the issuance of a sustainability report in column (3). GRI compliance signifies disclosure of broad, multistakeholder focused sustainability information according to GRI guidelines. Similarly, in column (3) we control for the issuance of a sustainability report, to account for general sustainability reporting. We note that neither GRI compliance nor the sustainability reporting controls are significant and controlling for them does not alter the result. The results in Table 4 are consistent with the hypothesis that disclosure of sustainability information according to SASB standards is associated with stock prices reflecting more firmspecific information. ${ }^{14}$

\subsection{Firm Sustainability Importance}

We expect the relation between material sustainability disclosure and stock price synchronicity to be moderated by the importance of sustainability issues. Firms for which sustainability matters more should

\footnotetext{
${ }^{14}$ In untabulated results, we also control for industry concentration (log of a revenue-based Herfindahl index of industry-level concentration). Consistent with Fernandes and Ferreira (2008), the coefficient on industry concentration is negative but insignificant, and our main results remain unchanged.
} 
experience a stronger association between sustainability disclosure and the firm-specific information content of the stock market. To capture firm sustainability importance, we employ two proxies. The first is a measure of a company's exposure to sustainability issues, obtained from MSCI Intangible Value Assessment (IVA) product, which identifies key ESG-driven risk and opportunity exposures relevant to a firm. Firms receive an annually updated, firm-specific rating that allows for a direct comparison between firms on their exposure to ESG issues. The second proxy is collected from Asset4, Thomson Reuters' principal product for sustainability information. It captures how well sustainability issues are integrated with financial issues as well as in a company's procedures. More specifically, our measure reflects whether these issues are integrated in management discussions and reviewed in the annual report. We expect firms with greater exposure to and integration of sustainability issues will experience a stronger firm-specific information effect in returns as material disclosure of sustainability information increases.

The results are provided in Table 5. In column (1) we include the interaction effect between a dummy variable equal to one if a firm has above-average sustainability exposure in year $t$, ESGExposure (mean $=0.45$, standard deviation $=0.54$ ), and material ESG disclosure, revealing a significant negative coefficient. Interpreting the coefficients in column (1), we find that material sustainability disclosure reduces stock price synchronicity by -0.40 more when the firm-exposure to ESG risks and opportunities according to MSCI IVA is above average. This is substantial and can explain 35\% of one standard deviation of variation in synchronicity. Column (2) provides the result for the interaction with above-average integration of sustainability issues, Integrated (mean $=0.55$, standard deviation $=0.36$ ), also producing a negative significant coefficient. We find that firms that integrate financial and ESG issues in their business, experience a stronger negative effect of material sustainability disclosure on stock price synchronicity by a magnitude of -0.53 ; this is approximately $46 \%$ of a standard deviation in synchronicity. Finally, we include both interactions together as shown in column (3). Both effects are significant suggesting that the effects are more pronounced for firms that are more economically exposed to sustainability issues and for firms that have integrated sustainability issues more into their business.

\subsection{Capital Market Participants}


We expect that capital market participants who are more adept at processing information will moderate a stronger effect of material sustainability disclosure on stock price synchronicity. Our first measure captures the level of institutional ownership. Institutional investors are expected to be more proficient in integrating material sustainability disclosure into stock prices compared to retail investors. Our second measure reflects the percentage shares of a firm that is held by socially responsible investment (SRI) funds. SRI funds have a history of integrating sustainability information in their investment decisions and consequently are expected to exhibit higher information-processing skills, particularly for information of this nature.

The results are provided in Table 6. Column (1) shows the results using institutional ownership as the moderator. We find that an increase in institutional ownership by one standard deviation, or 0.25 , decreases synchronicity by $37 \%$ of a standard deviation of synchronicity. In column (2), SRI fund ownership is used in the interaction and finally both moderators are considered jointly in column (3). For all specifications, we find a negative significant interaction effect. When including both measures of investor expertise together, we find that both institutional ownership as well as SRI ownership matter. Our results support our hypothesis that the relationship between material sustainability disclosure and stock price synchronicity is more negative when capital market participants are more proficient at processing sustainability information.

Moreover, we examine the role of sell-side analysts in moderating the relationship between sustainability information and synchronicity. Past literature has studied the relation between sustainability disclosures and ratings, and analyst recommendations (Ioannou and Serafeim 2015) or forecasts (Dhaliwal et al. 2012). Past research has also examined the relation between synchronicity and analyst forecasting intensity (which we control for in all of our models), documenting a positive relationship between the two (Piotroski et al. 2004). Consistent with our previous argument, we expect that analysts with lower information processing costs, due to lower portfolio complexity, will exhibit a stronger negative relationship between sustainability information and synchronicity. Following Clement (1999), and using data from $\mathrm{I} / \mathrm{B} / \mathrm{E} / \mathrm{S}$, we proxy for portfolio complexity using the number of stocks an analyst covers within a year. Analysts who cover a large number of different stocks may not be able to invest the same amount 
of research into any individual stock as compared to analysts who cover few stocks. To construct a firmyear measure of information processing costs, NumberCompanies (mean=16.47, standard deviation=3.31), we average the number of stocks across all analysts covering a firm in a given year. In the first column of Table 7, the positive coefficient on MaterialDisc $\times$ NumberCompanies confirms that the relationship between sustainability information and synchronicity is less negative for firms with higher analyst portfolio complexity, suggesting that analysts are important intermediaries of sustainability information.

The second column of Table 7 examines the role of firm-specific analyst experience, FirmExperience $($ mean=4.14, standard deviation=1.78). We proxy for analyst experience using the number of years an analyst has covered a specific stock, calculated using data from I/B/E/S. To construct a firmyear measure, we average the number of years of experience across all analysts covering a particular firm in a given year. On the one hand, we expect firms covered by more experienced analysts to exhibit a stronger negative relation between synchronicity and sustainability information, as more experienced analysts may be better able to process and translate the sustainability information for investors. On the other hand, we expect to document the opposite effect if more experienced analysts exhibit inertia and are less likely to use new sources of information. Past research documents that more experienced analysts are faster in switching from an agency to a stakeholder logic of sustainability efforts (Ioannou and Serafeim 2015), and as such, the inertia argument may be less likely to apply in our setting. However, one could still expect that experience positively moderates the negative relation between sustainability disclosure and synchronicity, if lack of experience and disclosure are complements. In other words, if less experienced analysts require more disclosure in order to incorporate sustainability information into their analysis, then greater levels of experience will positively moderate the association between disclosure and synchronicity. We find evidence in favor of this latter argument, as confirmed by the positive coefficient on MaterialDisc $\times$ FirmExperience, suggesting that firms with more experienced analysts have a less negative relation between sustainability information and synchronicity. Finally, column three includes the two moderating variables together and shows that they are both significant.

\subsection{Intra-industry Information Transfers}


An important stream of literature documents intra-industry information transfers whereby an idiosyncratic event that affects the short-window stock price of one firm (e.g., an earnings announcement by one firm, or an accounting restatement by one firm) also affects the contemporaneous short-window stock price of another firm in the same industry (Foster 1981; Gleason et al. 2008). Similarly, recent research documents cross-firm stock return predictability as a function of firm characteristics, specifically accounting quality, rather than to an information event (Chen et al. 2017). In this paper we investigate if intra-industry information transfers happen in the context of sustainability information. If information transfers exist, we expect that stock returns of firms that disclose little information about their material sustainability issues might exhibit higher co-movement with industry returns, if they belong to an industry where companies' disclosure levels are high. In contrast, we expect no effect on co-movement with industry returns for firms that disclose little information but belong to industries where companies' disclosure levels are low. We measure a firm's industry level information in stock returns following Piotroski and Roulstone (2004) as the difference between the explanatory power of market and industry returns versus only market returns. The higher the difference, the more a firm's stock returns contain industry-level information.

Table 8 present the results for this analysis. We find strong evidence that firms with low disclosure levels exhibit high industry-level synchronicity within the whole sample and that this result is driven only by firms in industries with rich information environment (i.e. industries having above average industrylevel sustainability disclosure scores). In untabulated results, we document that intra-industry information transfers are stronger for firms with greater exposure to sustainability issues and with a higher percentage of shares held by institutional investors.

\subsection{Additional Analyses}

\subsubsection{Other Sustainability Disclosures}

In testing for the relation between material sustainability disclosures and synchronicity we have controlled for both compliance with GRI standards and whether a firm issues a sustainability report. However, firms disclose a wealth of sustainability information through other mediums, primarily their websites, even if they do not issue a separate report. We attempt to understand whether a firm's sustainability disclosures not 
included in SASB standards also have a negative association with synchronicity. Therefore, we construct a measure of ESG disclosure that is comprised of the total ESG disclosure score that Bloomberg calculates after orthogonalizing this measure with our materiality disclosure score. ${ }^{15}$ Effectively, this score captures a firm's level of ESG disclosure that is unrelated to its level of material sustainability disclosure. In Table 9 we find that this measure exhibits an insignificant association with synchronicity. In untabulated tests, we do not find that the measure is correlated with synchronicity in any of our moderating variable tests.

\subsubsection{Earnings Quality}

Firms that disclose more material sustainability information could also have different financial accounting characteristics, importantly earnings quality. Although not assessing disclosures, Kim, Park and Weir (2012) find that firms with good performance ratings on sustainability issues have higher earnings quality. Thus, earnings quality could be a correlated omitted variable if material sustainability disclosure is related to earnings quality. Prior literature is inconclusive on the relation between earnings quality and synchronicity. Durnev et al. (2003), Ferreira and Laux (2007) and Hutton et al. (2009) document that poor earnings quality is associated with lower firm-specific return variation, while Fernandes and Ferreira (2008) and Gul, Ng and Srinidhi (2001) find no relation between earnings quality and synchronicity. We follow Dechow and Dichev (2002), using the residuals from estimating a model of working capital accruals on lagged, current and future cash flows to estimate poor earnings quality (Poor_AQ). As another proxy for earnings quality, we compute the absolute value of firm accruals scaled by the absolute value of cash flow from operations (ABS_ACCR). In univariate correlations, we find a negative and significant (-0.0929, $\mathrm{p}<0.000$ ) relationship between material ESG disclosure and ABS_ACCR, and a negative but insignificant relation with Poor_AQ $(-0.0461, \mathrm{p}<0.183)$. All of our aforementioned results are robust to controlling for Poor_AQ and ABS_ACCR.

\subsubsection{Validity of Synchronicity Measure}

${ }^{15}$ The Bloomberg disclosure score is calculated taking into account all ESG data items in the Bloomberg database. 
Li et al. (2014) suggest that lower synchronicity could be a proxy for firm-specific information or noise in stock prices. Motivated by the fact that examining stock price synchronicity and idiosyncratic volatility sometimes produce different inferences, they suggest that researchers should understand if their results are robust when controlling for betas, and testing if the hypothesized relation between the independent variable of interest and synchronicity changes sign or remains the same. This is because a decrease in synchronicity could be driven by a decrease in beta and/or an increase in idiosyncratic volatility. If it changes sign, then this would be inconsistent with the proposed theory, as it would provide evidence that the relation between the independent variable of interest and idiosyncratic volatility is opposite to what is being predicted.

In Table 10 we control for the market and industry betas in our regression model. We find that even when we control for market beta in columns (1) and (2), the relationship between material sustainability disclosure and synchronicity is negative and significant suggesting that firms with higher material sustainability disclosure have higher idiosyncratic volatility. In columns (3) and (4) we control for industry beta, and finally in columns (5) and (6) we control for both market and industry beta together. Across all specifications, the coefficient on sustainability disclosure remains negative and significant.

\section{CONCLUSION}

Our paper seeks to provide evidence on the characteristics of emerging accounting standards for sustainability information. Given that a large number of institutional investors seek sustainability data and have committed to use sustainability data, it is becoming increasingly important to develop a robust accounting infrastructure for the reporting of such information. In this paper, we test whether companies that voluntarily disclosed information, before the standards identified this information as investor-relevant, had lower stock price synchronicity.

We find strong evidence that this is the case. Perhaps more importantly, we find that this association is moderated in predictable ways. The association is stronger for firms that are more exposed to sustainability issues and for firms that have integrated sustainability issues more into their business operations and strategy. We also find that the association is stronger when investors with higher 
sustainability information processing capabilities hold the shares of the firm. These results not only increase our confidence that sustainability information rather than a correlated omitted variable drive the association, but also shed incremental light on firm and capital market characteristics that accentuate the relation. Furthermore, we document intra-industry information transfers, measured as increases in industry-level stock price synchronicity, for firms that have low transparency but are in industries with relatively high levels of sustainability disclosure. We also document that analyst characteristics (i.e. portfolio complexity and firm-specific experience) moderate the relation between sustainability information and synchronicity, adding new insights to the studies that examine analysts and sustainability information (Ioannou and Serafeim 2015 and Dhaliwal et al. 2012) as well as analyst activities and synchronicity (Piotroski et al. 2004).

Our paper is a first attempt to understand development of accounting standards for disclosure of sustainability information. Although SASB standards are still new, preventing researchers from documenting robust consequences from these standards, there will be exciting opportunities for research in the future. First, there is a need for field research that examines how companies react and use the standards in managing and reporting performance on different sustainability issues. Which companies adopt the standards first and why? What drives diffusion of standards across companies? Second, there is a need for empirical work that examines the consequences that standards have on the comparability of reported information. Do disclosures converge within an industry and diverge across industries? Third and perhaps most importantly, how do standards drive change inside organizations? Do they elevate the importance of sustainability issues inside organizations by assigning responsibility over sustainability issues at the board level, or using these metrics in executive compensation plans (Eccles et al. 2014)? These and other questions represent fruitful avenues for future research. 


\section{REFERENCES}

Allee, K.D. and Yohn, T.L., 2009. The demand for financial statements in an unregulated environment: An examination of the production and use of financial statements by privately held small businesses. The Accounting Review, 84(1), pp.1-25.

Allen, A.M., and Ramanna, K. 2013. Towards an Understanding of the Role of Standard Setters in Standard Setting. Journal of Accounting \& Economics 55, no. 1: 66-90.

Amel-Zadeh, A. and Serafeim, G. 2017. Why and How Investors Use ESG Information: Evidence from a Global Survey. Harvard Business School Working Paper.

Barth, M.E., Landsman, W.R. and Lang, M.H., 2008. International accounting standards and accounting quality. Journal of Accounting Research, 46(3), pp.467-498.

Barth, M., Li. K., and McClure, C.G. 2017. Evolution in Value Relevance of Accounting Information. Working paper.

Beatty, A., S. Chamberlain, and J. Magliolo. 1996. An empirical analysis of the economic implications of fair value accounting for investment securities. Journal of Accounting and Economics 22: 43-77.

Bushee, B.J. and Miller, G.S., 2012. Investor relations, firm visibility, and investor following. The Accounting Review, 87(3), pp.867-897.

Bratten, B., Choudhary, P. and Schipper, K., 2013. Evidence that market participants assess recognized and disclosed items similarly when reliability is not an issue. The Accounting Review, 88(4), pp.1179-1210.

Chen, W., Khan, M., Kogan, L. and Serafeim, G., 2017. Cross-Firm Return Predictability and Accounting Quality. Working paper.

Cheng, B., I. Ioannou, and G. Serafeim. 2014. Corporate social responsibility and access to finance. Strategic Management Journal 35, no. 1: 1-23.

Clement, M.B., 1999. Analyst forecast accuracy: Do ability, resources, and portfolio complexity matter?. Journal of Accounting and Economics, 27(3), pp.285-303.

Collins, D.W., Maydew, E.L., and I.S. Weiss. 1997. Changes in the value-relevance of earnings and book values over the past forty years. Journal of Accounting and Economics 24: 39-67.

Cornett, M., Z. Rezaee, and H. Tehranian. 1996. An investigation of capital market reactions to pronouncements on fair value accounting. Journal of Accounting and Economics 22: 119-154.

Crawford, S. S., D. T. Roulstone, and E. C. So. 2012. Analyst initiations of coverage and stock return synchronicity. The Accounting Review 87: 1527-1553.

Dechow, P. And Dichev, I. 2002. The Quality of Accruals and Earnings: The Role of Accrual Estimation Errors. The Accounting Review 77: 35-59.

Dechow, P., A. Hutton, and R. Sloan. 1996. Economic consequences of accounting for stock-based compensation. Journal of Accounting Research 34 (1996): 1-20. 
Dhaliwal, D., O. Li, A. Tsang, and Y. Yang. 2011. Voluntary nonfinancial disclosure and the cost of equity capital: the initiation of corporate social responsibility reporting. The Accounting Review 86: 59-100.

Dhaliwal, D.S., Radhakrishnan, S., Tsang, A. and Yang, Y.G., 2012. Nonfinancial disclosure and analyst forecast accuracy: International evidence on corporate social responsibility disclosure. The Accounting Review, 87(3), pp.723-759.

Durnev, A., Morck, R., Yeung, B. and Zarowin, P. 2003. Does Greater Firm-Specific Return Variation Mean More or Less Informed Stock Pricing? Journal of Accounting Research 41: 797-836.

Durnev, A., Morck, R., and Yeung, B. 2004. Value-Enhancing Capital Budgeting and Firm-Specific Stock Return Variation. Journal of Finance 59: 65-105

Eccles, R., Ioannou, I. and Serafeim, G. 2014. The Impact of Corporate Sustainability on Organizational Processes and Performance. Management Science 60: 2835-2857.

Ferreira, M. and Laux, P. 2007. Corporate Governance, Idiosyncratic Risk, and Information Flow. Journal of Finance 62: 951-989.

Fernandes, N. and Ferreira, M. 2008. Does international cross-listing improve the information environment? Journal of Financial Economics 88: 216-244.

Ferreira, D., Ferreira, M. and Raposo, C. 2011. Board Structure and price informativeness. Journal of Financial Economics 99: 523-545.

Foster, G. 1981. Intra-industry information transfers associated with earnings releases. Journal of Accounting and Economics 3, 201-232.

Francis, J., and K. Shipper. 1999. Have financial statements lost their value relevance? Journal of Accounting Research 37(2): 319-352.

Gleason, C., N. T. Jenkins, and W. B. Johnson. 2008. The contagion effects of accounting restatements. The Accounting Review 83, 83-110.

Grewal, J., Rield, E. and Serafeim, G. 2017. Market Reaction to Mandatory Nonfinancial Disclosure. Harvard Business School Working Paper.

Gul, F., Srinidhi, B. And Ng, A. 2011. Does board gender diversity improve the informativeness of stock prices? Journal of Accounting and Economics 51: 314-338.

Healy, P. M., and K. G. Palepu. 2001. Information asymmetry, corporate disclosure, and the capital markets: A review of the empirical disclosure literature. Journal of Accounting and Economics 31: 405-440.

Hutton, A., Marcus, A. and Tehranian, H. 2009. Opaque financial reports, R2, and crash risk. Journal of Financial Economics 94: 67-86.

Ioannou, I. and Serafeim, G., 2015. The impact of corporate social responsibility on investment recommendations: Analysts' perceptions and shifting institutional logics. Strategic Management Journal, 36(7), pp.1053-1081. 
Khan, M., Serafeim, G. and Yoon, A. Corporate Sustainability: First Evidence on Materiality. The Accounting Review 91: 1697-1724.

Kim, Y., Park, M. and Wier, B. 2012. Is Earnings Quality Associated with Corporate Social Responsibility? The Accounting Review 87: 761-796.

Levitt, A., 1998. The importance of high quality accounting standards. Accounting horizons, 12 (1), p.7982.

Li, B., Shivaram R. and Venkatachalam M. 2014. $\mathrm{R}^{2}$ and Idiosyncratic Risk Are Not Interchangeable. The Accounting Review 89: 2261-2295.

Naughton, J., Petacchi, R. and Weber, J., 2015. Public pension accounting rules and economic outcomes. Journal of Accounting and Economics, 59 (2), pp.221-241.

Peterson, K., Schmardebeck, R. and Wilks T.J. 2015. The Earnings Quality and Information Processing Effects of Accounting Consistency. The Accounting Review 90: 2483-2514.

Piotroski, J. D., and D. T. Roulstone. 2004. The influence of analysts, institutional investors, and insiders on the incorporation of market, industry, and firm-specific information into stock prices. The Accounting Review 79: 1119-1151.

Ramanna, Karthik. 2008. "he Implications of Unverifiable Fair-value Accounting: Evidence from the Political Economy of Goodwill Accounting. Journal of Accounting \& Economics 45, nos. 2-3: 253-281.

Roll, R. 1988. R2. Journal of Finance 43:541-566.

Serafeim, G., 2011. Consequences and institutional determinants of unregulated corporate financial statements: Evidence from embedded value reporting. Journal of Accounting Research, 49(2), pp.529-571.

Wurgler, J. 2000. Financial markets and the allocation of capital. Journal of Financial Economics 58: 187214. 
Appendix A: Variable definitions

\begin{tabular}{|c|c|}
\hline Synchronicity $_{i, t}$ & $\begin{array}{l}\text { Firm } i \text { 's stock price synchronicity in year } t \text {, measured as } \log \left(\frac{R^{2}}{1-R^{2}}\right) \text { from the } \\
\text { annual firm-specific regression of daily firm returns on value-weighted market and } \\
\text { industry returns. }\end{array}$ \\
\hline MaterialDisc $_{i, t}$ & $\begin{array}{l}\text { Ratio of the number of disclosed SASB ESG metrics to the total number of SASB } \\
\text { ESG metrics available in Bloomberg, for firm } i \text { in year } t \text {. }\end{array}$ \\
\hline MarketCap $_{i, t}$ & The natural logarithm of market capitalization for firm $i$ in year $t$, from Compustat. \\
\hline GRICompl $_{i, t}$ & $\begin{array}{l}\text { A Bloomberg variable equal to } 1 \text { if firm } i \text { is compliant with GRI guidelines in year } \\
t, 0 \text { otherwise. }\end{array}$ \\
\hline SustReport $_{i, t}$ & $\begin{array}{l}\text { A variable equal to } 1 \text { if firm } i \text { issues a sustainability report in year } t, 0 \text { otherwise. } \\
\text { Computed using data from Thomson Reuters Asset4, CorporateRegister and } \\
\text { Bloomberg. }\end{array}$ \\
\hline InstOwn $n_{i, t}$ & $\begin{array}{l}\text { The percentage of firm } i \text { 's ownership by institutional shareholders in year } t \text {, from } \\
\text { Thomson Reuters Ownership. }\end{array}$ \\
\hline AnalystRev $_{i, t}$ & $\begin{array}{l}\text { Natural logarithm of the number of analyst revisions for firm } i \text { in year } t \text { from } \\
\text { I/B/E/S. }\end{array}$ \\
\hline$M T B_{i, t}$ & Market to book value for firm $i$ in year $t$, computed using data from Compustat. \\
\hline$S_{t d D e v R O A}{ }_{i, t}$ & $\begin{array}{l}\text { Standard deviation of quarterly ROA, measured over the three years preceding and } \\
\text { including } t \text { for firm } i \text {, computed using Compustat. }\end{array}$ \\
\hline InsiderTrades $i, t$ & $\begin{array}{l}\text { Natural logarithm of the absolute value of net trading by insiders scaled by annual } \\
\text { trading volume for firm } i \text { in year } t \text {, computed using CRSP. }\end{array}$ \\
\hline ESGExposure $_{i, t}$ & $\begin{array}{l}\text { A variable equal to } 1 \text { if firm } i \text { has above-median exposure to ESG-driven risks and } \\
\text { opportunities in year } t \text {, as defined by MSCI IVA, } 0 \text { otherwise. }\end{array}$ \\
\hline Integrated $_{i, t}$ & $\begin{array}{l}\text { A variable equal to } 1 \text { if firm } i \text { has above-median integration of sustainability issues } \\
\text { across its core business in year } t \text {, as defined by Thomson Reuters Asset } 4,0 \\
\text { otherwise. }\end{array}$ \\
\hline SRIOwn ${ }_{i, t}$ & $\begin{array}{l}\text { The percentage of firm } i \text { 's ownership by socially responsible investment funds in } \\
\text { year } t \text {, calculated using Thomson Reuters Ownership data and Bloomberg. }\end{array}$ \\
\hline MarketBeta $_{i, t}$ & $\begin{array}{l}\text { Coefficient estimate of market returns from the regression of daily firm returns on } \\
\text { value-weighted market and industry returns, for firm } i \text { in year } t \text {. }\end{array}$ \\
\hline IndustryBeta $_{i, t}$ & $\begin{array}{l}\text { Coefficient estimate of industry returns from the regression of daily firm returns on } \\
\text { value-weighted market and industry returns, for firm } i \text { in year } t \text {. }\end{array}$ \\
\hline$R 2 D_{i f f}$ & $\begin{array}{l}\text { The difference between the explanatory power from the annual firm-specific } \\
\text { regression of daily firm returns on value-weighted market and industry returns and } \\
\text { the explanatory power from value-weighted market returns. }\end{array}$ \\
\hline LowDisclosure $_{i, t}$ & $\begin{array}{l}\text { An indicator variable taking the value of one for firms with below average } \\
\text { MaterialDisc in year } t \text {. }\end{array}$ \\
\hline NumberCompanies ${ }_{i, t}$ & $\begin{array}{l}\text { The average number of companies in analyst coverage across all analysts covering } \\
\text { firm } i \text { in year } t \text {. }\end{array}$ \\
\hline FirmExperience $i, t$ & $\begin{array}{l}\text { The average number of years an analyst follows firm } \mathrm{i} \text { across all analysts covering } \\
\text { firm } i \text { in year } t \text {. }\end{array}$ \\
\hline
\end{tabular}


Table 1

Sample Selection

Bloomberg ESG coverage

Unique firms

9,064

Less: Missing ESG disclosure data

$(1,662)$

Less: Non-US listed firms

$(5,037)$

Less: Financial and utility companies

Less: Missing required financial information

Total number of unique firms in sample

1,333

Firm years

Unique firms $\times$ number of years

10,664

Less: Missing year-specific financial information

(257)

Total number of firm-year observations in sample

10,407

Table 2

Frequencies

Panel A. Year

\begin{tabular}{lll} 
Year & Frequency & Percent \\
\hline 2007 & 1,267 & 12.17 \\
2008 & 1,310 & 12.59 \\
2009 & 1,312 & 12.61 \\
2010 & 1,317 & 12.65 \\
2011 & 1,326 & 12.74 \\
2012 & 1,326 & 12.74 \\
2013 & 1,324 & 12.72 \\
2014 & 1,225 & 11.77 \\
\hline Total & $\mathbf{1 0 , 4 0 7}$ & $\mathbf{1 0 0}$
\end{tabular}




\begin{tabular}{|c|c|c|c|c|c|}
\hline Panel B. Industry & Frequency & Percent & Industry & Frequency & Percent \\
\hline Advertising \& Marketing & 48 & 0.46 & Household Products & 141 & 1.35 \\
\hline Aerospace \& Defense & 230 & 2.21 & Industrial Machinery \& Goods & 771 & 7.41 \\
\hline Agricultural Products & 80 & 0.77 & Internet Media \& Services & 100 & 0.96 \\
\hline Air Freight \& Logistics & 78 & 0.75 & Iron \& Steel Producers & 111 & 1.07 \\
\hline Airlines & 62 & 0.60 & Leisure Facilities & 112 & 1.08 \\
\hline Alcoholic Beverages & 32 & 0.31 & Managed Care & 100 & 0.96 \\
\hline Apparel \& Accessories & 431 & 4.14 & Marine Transportation & 48 & 0.46 \\
\hline Appliance Manufacturing & 39 & 0.37 & Meat, Poultry \& Dairy & 52 & 0.50 \\
\hline Auto Parts & 132 & 1.27 & Media Production & 192 & 1.84 \\
\hline Automobiles & 68 & 0.65 & Medical Equipment \& Supplies & 536 & 5.15 \\
\hline Biofuels & 23 & 0.22 & Metals \& Mining & 119 & 1.14 \\
\hline Biotechnology & 302 & 2.90 & Multiline Specialty Retailers & 589 & 5.66 \\
\hline Building Products & 164 & 1.58 & Non-Alcoholic Beverages & 45 & 0.43 \\
\hline Cable \& Satellite & 23 & 0.22 & Oil \& Gas Production & 436 & 4.19 \\
\hline Car Rental \& Leasing & 16 & 0.15 & Oil \& Gas-Midstream & 56 & 0.54 \\
\hline Casinos \& Gaming & 72 & 0.69 & Oil \& Gas-Refining & 82 & 0.79 \\
\hline Chemicals & 375 & 3.60 & Oil \& Gas-Services & 299 & 2.87 \\
\hline Coal Operations & 21 & 0.20 & Pharmaceuticals & 266 & 2.56 \\
\hline Construction Materials & 79 & 0.76 & Processed Foods & 149 & 1.43 \\
\hline Containers \& Packaging & 135 & 1.30 & Professional Services & 436 & 4.19 \\
\hline Cruise Lines & 8 & 0.08 & Pulp \& Paper Products & 30 & 0.29 \\
\hline Drug Retailers & 31 & 0.30 & Rail Transportation & 40 & 0.38 \\
\hline E-Commerce & 64 & 0.61 & Restaurants & 197 & 1.89 \\
\hline Education & 92 & 0.88 & Road Transportation & 94 & 0.90 \\
\hline Electrical Equipment & 270 & 2.59 & Semiconductors & 504 & 4.84 \\
\hline Electronic Manufacturing & 63 & 0.61 & Software \& IT Services & 707 & 6.79 \\
\hline Food Retailers \& Distributors & 86 & 0.83 & Solar Energy & 38 & 0.37 \\
\hline Fuel Cells & 31 & 0.30 & Telecommunications & 218 & 2.09 \\
\hline Hardware & 460 & 4.42 & Tobacco & 46 & 0.44 \\
\hline Health Care Delivery & 235 & 2.26 & Toys \& Sporting Goods & 39 & 0.37 \\
\hline Health Care Distributors & 72 & 0.69 & & & \\
\hline Hotels \& Lodging & 32 & 0.31 & Total & 10,407 & 100 \\
\hline
\end{tabular}


Table 3

Descriptive Statistics

Panel A. Descriptive Data $(N=10,407)$

\begin{tabular}{lrrrrr} 
Variable & Mean & Std. Dev. & Q1 & Median & Q3 \\
\hline Synchronicity & -0.523 & 1.150 & -1.057 & -0.444 & 0.138 \\
MaterialDisc & 0.172 & 0.184 & 0.000 & 0.125 & 0.268 \\
MarketCap & 21.160 & 1.736 & 19.926 & 20.973 & 22.253 \\
GRICompl & 0.083 & 0.276 & 0.000 & 0.000 & 0.000 \\
SustReport & 0.183 & 0.387 & 0.000 & 0.000 & 0.000 \\
InstOwn & 0.768 & 0.250 & 0.658 & 0.830 & 0.936 \\
AnalystRev & 0.873 & 1.025 & 0.000 & 0.693 & 1.609 \\
MTB & 3.619 & 5.713 & 1.343 & 2.229 & 3.812 \\
StdDevROA & 0.056 & 0.076 & 0.014 & 0.029 & 0.064 \\
InsiderTrades & 0.112 & 0.280 & 0.004 & 0.023 & 0.095 \\
\hline
\end{tabular}

Panel B. Correlations $(N=10,407)$

\begin{tabular}{|c|c|c|c|c|c|c|c|c|c|}
\hline Variable & (1) & (2) & (3) & (4) & $(5)$ & $(6)$ & $(7)$ & $(8)$ & (9) \\
\hline (1) Synchronicity & 1 & & & & & & & & \\
\hline (2) MaterialDisc & 0.2636 & 1 & & & & & & & \\
\hline (3) MarketCap & 0.5477 & 0.5979 & 1 & & & & & & \\
\hline (4) GRICompl & 0.1780 & 0.4510 & 0.4279 & 1 & & & & & \\
\hline (5) SustReport & 0.2480 & 0.5457 & 0.5480 & 0.6351 & 1 & & & & \\
\hline (6) InstOwn & 0.3154 & 0.1194 & 0.3046 & 0.0181 & 0.0556 & 1 & & & \\
\hline (7) AnalystRev & 0.2045 & 0.2100 & 0.3369 & 0.1479 & 0.1806 & 0.1533 & 1 & & \\
\hline (8) МTB & 0.0132 & 0.0273 & 0.0865 & 0.0291 & 0.0208 & -0.0319 & -0.0348 & 1 & \\
\hline (9) StdDevROA & -0.2833 & -0.1969 & -0.3309 & -0.0966 & -0.1451 & -0.2544 & -0.0534 & 0.1148 & 1 \\
\hline (10) InsiderTrades & -0.0603 & -0.0240 & -0.0095 & -0.0566 & -0.0755 & -0.0721 & -0.0342 & 0.0424 & -0.0646 \\
\hline
\end{tabular}

This table presents descriptive statistics. Panel A presents descriptive data. Panel B presents Pearson correlations; bolded numbers represent significance at 5\% level or higher. All variables are winsorized at the 1- and 99-percent levels, and defined in Appendix A. 
Table 4

Relation between Material Sustainability Information and Stock Price Synchronicity

\begin{tabular}{|c|c|c|c|c|c|c|}
\hline \multirow[b]{2}{*}{ Variable } & \multicolumn{2}{|c|}{$\begin{array}{c}\text { (1) } \\
\text { Dependent variable: } \\
\text { Synchronicity }\end{array}$} & \multicolumn{2}{|c|}{$\begin{array}{c}\text { (2) } \\
\text { Dependent variable: } \\
\text { Synchronicity }\end{array}$} & \multicolumn{2}{|c|}{$\begin{array}{c}\text { (3) } \\
\text { Dependent variable: } \\
\text { Synchronicity }\end{array}$} \\
\hline & Coef. & $t$-stat & Coef. & $t$-stat & Coef. & $t$-stat \\
\hline MaterialDisc & -0.5135 & -4.47 & -0.5048 & -4.29 & -0.4676 & -3.90 \\
\hline GRICompl & & & -0.0124 & -0.24 & & \\
\hline SustReport & & & & & -0.0452 & -1.05 \\
\hline MarketCap & 0.3794 & 24.48 & 0.3798 & 24.35 & 0.3824 & 23.92 \\
\hline InstOwn & 0.5979 & 6.89 & 0.5968 & 6.87 & 0.5923 & 6.88 \\
\hline AnalystRev & -0.0067 & -0.62 & -0.0067 & -0.62 & -0.0067 & -0.62 \\
\hline MTB & 0.0016 & 0.81 & 0.0016 & 0.81 & 0.0015 & 0.77 \\
\hline StdDevROA & -0.9769 & -3.80 & -0.9765 & -3.80 & -0.9711 & -3.78 \\
\hline InsiderTrades & -0.1114 & -2.24 & -0.1119 & -2.25 & -0.1149 & -2.32 \\
\hline Intercept & -8.6373 & -25.09 & -8.6478 & -24.89 & -8.7138 & -24.30 \\
\hline$N$ & 10,407 & & 10,40 & & 10, & \\
\hline Adjusted- $R^{2}$ & 0.57 & & 0.57 & & 0.5 & \\
\hline Fixed effects & Year, Indu & & Year, Ind & & Year, Ir & try \\
\hline
\end{tabular}

This table presents results of multivariate analyses of stock return synchronicity regressed on material sustainability disclosure and other control variables. All variables are winsorized at the 1- and 99-percent levels, and defined in Appendix A. Regressions include year and industry fixed effects, with standard errors clustered by firm. 


\section{Table 5}

Firm Exposure Moderators

\begin{tabular}{|c|c|c|c|c|c|c|}
\hline \multirow[b]{3}{*}{ Variable } & \multicolumn{4}{|c|}{$\begin{array}{c}\text { Integrated Financial } \\
\text { and Sustainability } \\
\text { issues }\end{array}$} & \multicolumn{2}{|c|}{$\begin{array}{l}\text { Both moderators } \\
\text { together }\end{array}$} \\
\hline & \multicolumn{2}{|c|}{$\begin{array}{c}\text { (1) } \\
\text { Dependent variable: } \\
\text { Synchronicity }\end{array}$} & \multicolumn{2}{|c|}{$\begin{array}{c}(2) \\
\text { Dependent variable: } \\
\text { Synchronicity }\end{array}$} & \multicolumn{2}{|c|}{$\begin{array}{c}(3) \\
\text { Dependent variable: } \\
\text { Synchronicity }\end{array}$} \\
\hline & Coef. & $t$-stat & Coef. & $t$-stat & Coef. & $t$-stat \\
\hline MaterialDisc & -0.1969 & -1.07 & -0.0967 & -0.58 & 0.2730 & 1.25 \\
\hline MaterialDisc $\times$ ESGExposure & -0.4042 & -2.09 & & & -0.4703 & -2.41 \\
\hline MaterialDisc $\times$ Integrated & & & -0.5293 & -3.59 & -0.5963 & -4.11 \\
\hline Integrated & & & 0.0210 & 0.37 & 0.0911 & 2.27 \\
\hline ESGExposure & 0.0864 & 2.14 & & & 0.0429 & 0.76 \\
\hline SustReport & -0.0334 & -0.79 & -0.0582 & -1.35 & -0.0450 & -1.07 \\
\hline MarketCap & 0.3807 & 22.85 & 0.3800 & 23.12 & 0.3797 & 22.05 \\
\hline InstOwn & 0.5817 & 6.81 & 0.5912 & 6.85 & 0.5792 & 6.78 \\
\hline AnalystRev & -0.0064 & -0.59 & -0.0067 & -0.62 & -0.0060 & -0.56 \\
\hline МТВ & 0.0017 & 0.86 & 0.0013 & 0.70 & 0.0015 & 0.81 \\
\hline StdDevROA & -0.9718 & -3.83 & -0.9853 & -3.83 & -0.9850 & -3.88 \\
\hline InsiderTrades & -0.1185 & -2.4 & -0.1159 & -2.34 & -0.1205 & -2.44 \\
\hline Intercept & -8.7447 & -23.31 & -8.6459 & -22.29 & -8.7355 & -21.40 \\
\hline$N$ & 10,40 & & 10,4 & & 10,4 & \\
\hline Adjusted- $R^{2}$ & 0.56 & & 0.5 & & 0.57 & \\
\hline Fixed effects & Year, Inc & & Year, In & & Year, In & \\
\hline
\end{tabular}

This table presents results of multivariate analyses of stock return synchronicity regressed on material sustainability disclosure interacted with firm-level variables of exposure to ESG issues, and other control variables. All variables are winsorized at the 1- and 99-percent levels, and defined in Appendix A. Regressions include year and industry fixed effects, with standard errors clustered by firm. 


\section{Table 6}

Capital Market Participant Moderators

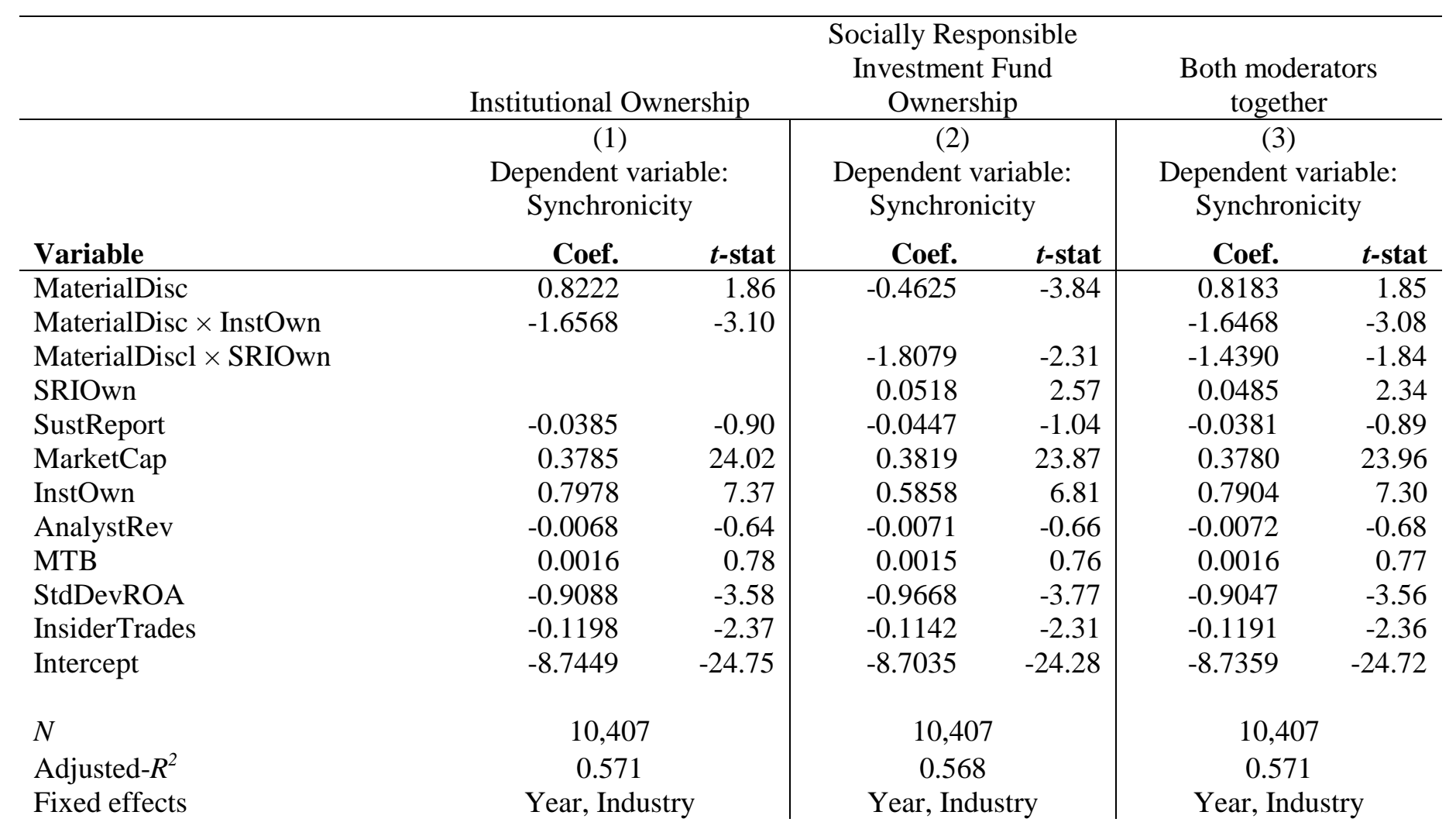

This table presents results of multivariate analyses of stock return synchronicity regressed on material sustainability disclosure interacted with firm-level variables of institutional ownership and SRI fund ownership, and other control variables. All variables are winsorized at the 1- and 99percent levels, and defined in Appendix A. Regressions include year and industry fixed effects, with standard errors clustered by firm. 
Table 7

Sell-side Analyst Moderators

\begin{tabular}{|c|c|c|c|c|c|c|}
\hline \multirow[b]{3}{*}{ Variable } & \multicolumn{2}{|c|}{$\begin{array}{c}\text { Analyst Portfolio } \\
\text { Complexity }\end{array}$} & \multicolumn{2}{|c|}{ Analyst Experience } & \multicolumn{2}{|c|}{ Both moderators together } \\
\hline & \multicolumn{2}{|c|}{$\begin{array}{c}(1) \\
\text { Dependent variable: } \\
\text { Synchronicity }\end{array}$} & \multicolumn{2}{|c|}{$\begin{array}{c}\text { (2) } \\
\text { Dependent variable: } \\
\text { Synchronicity }\end{array}$} & \multicolumn{2}{|c|}{$\begin{array}{c}\text { (3) } \\
\text { Dependent variable: } \\
\text { Synchronicity }\end{array}$} \\
\hline & Coef. & $t$-stat & Coef. & $t$-stat & Coef. & $t$-stat \\
\hline MaterialDisc & -1.2587 & -3.20 & -0.8844 & -3.60 & -1.4702 & -3.60 \\
\hline MaterialDisc $\times$ NumberCompanies & 0.0545 & 2.50 & & & 0.0399 & 1.80 \\
\hline MaterialDiscl × FirmExperience & & & 0.1075 & 2.54 & 0.0931 & 2.13 \\
\hline NumberCompanies & -0.0043 & -0.77 & & & -0.0055 & -0.99 \\
\hline FirmExperience & & & 0.0149 & 1.62 & 0.0171 & 1.86 \\
\hline SustReport & -0.0255 & -0.62 & -0.0453 & -1.11 & -0.0457 & -1.12 \\
\hline MarketCap & 0.3592 & 24.14 & 0.3522 & 23.66 & 0.3524 & 23.62 \\
\hline InstOwn & 0.3640 & 4.75 & 0.3661 & 4.85 & 0.3628 & 4.79 \\
\hline AnalystRev & -0.0220 & -2.16 & -0.0182 & -1.78 & -0.0185 & -1.82 \\
\hline MTB & 0.0019 & 0.98 & 0.0020 & 1.00 & 0.0021 & 1.07 \\
\hline StdDevROA & -0.6026 & -2.67 & -0.5867 & -2.65 & -0.5768 & -2.56 \\
\hline InsiderTrades & -0.1431 & -2.62 & -0.1209 & -2.29 & -0.1200 & -2.27 \\
\hline Intercept & -7.9979 & -26.07 & -7.9771 & -25.17 & -7.8903 & -25.90 \\
\hline$N$ & \multicolumn{2}{|c|}{9,371} & \multicolumn{2}{|c|}{9,371} & \multicolumn{2}{|c|}{9,371} \\
\hline Adjusted- $R^{2}$ & \multirow{2}{*}{\multicolumn{2}{|c|}{$\begin{array}{c}0.582 \\
\text { Year, Industry }\end{array}$}} & \multirow{2}{*}{\multicolumn{2}{|c|}{$\begin{array}{c}0.585 \\
\text { Year, Industry }\end{array}$}} & \multirow{2}{*}{\multicolumn{2}{|c|}{$\begin{array}{c}0.585 \\
\text { Year, Industry }\end{array}$}} \\
\hline Fixed effects & & & & & & \\
\hline
\end{tabular}

This table presents results of multivariate analyses of stock return synchronicity regressed on material ESG disclosure interacted with firm-level variables of analyst coverage characteristics, and other control variables. All variables are winsorized at the 1- and 99-percent levels, and defined in Appendix A. Regressions include year and industry fixed effects, with standard errors clustered by firm. 


\section{Table 8}

Incremental Explanatory Power of Industry-level Returns

\begin{tabular}{|c|c|c|c|c|c|c|}
\hline \multicolumn{7}{|l|}{ Low Disclosure Firms } \\
\hline \multirow[b]{3}{*}{ Variable } & \multirow{2}{*}{\multicolumn{2}{|c|}{$\begin{array}{l}\text { (1) } \\
\text { Full Sample }\end{array}$}} & \multirow{2}{*}{\multicolumn{2}{|c|}{$\begin{array}{c}(2) \\
\text { Rich Information } \\
\text { Environment }\end{array}$}} & \multirow{2}{*}{\multicolumn{2}{|c|}{$\begin{array}{c}(3) \\
\text { Poor Information } \\
\text { Environment }\end{array}$}} \\
\hline & & & & & & \\
\hline & Coef. & $t$-stat & Coef. & $t$-stat & Coef. & $t$-stat \\
\hline LowDisclosure & 0.0153 & 2.83 & 0.0316 & 4.32 & -0.0081 & -1.06 \\
\hline SustReport & 0.0070 & 0.99 & 0.0124 & 1.32 & -0.0026 & -0.25 \\
\hline MarketCap & 0.0615 & 30.91 & 0.064 & 22.67 & 0.0578 & 23.06 \\
\hline InstOwn & 0.0530 & 5.00 & 0.063 & 3.91 & 0.0398 & 3.15 \\
\hline AnalystRev & -0.0006 & -0.30 & 0.0012 & 0.43 & -0.0034 & -1.44 \\
\hline MTB & -0.0002 & -0.54 & -0.0003 & -0.46 & -0.0002 & -0.49 \\
\hline StdDevROA & -0.0916 & -3.03 & -0.1505 & -2.55 & -0.0708 & -2.40 \\
\hline InsiderTrades & -0.0415 & -6.82 & -0.0491 & -6.21 & -0.0234 & -3.08 \\
\hline Intercept & -1.0837 & -23.77 & -1.1332 & -18.58 & -1.0069 & -17.2 \\
\hline$N$ & \multicolumn{2}{|c|}{10,407} & \multicolumn{2}{|c|}{5,534} & \multicolumn{2}{|c|}{4,873} \\
\hline Adjusted- $R^{2}$ & \multicolumn{2}{|c|}{0.65} & \multicolumn{2}{|c|}{0.644} & \multicolumn{2}{|c|}{0.66} \\
\hline \multirow[t]{3}{*}{ Fixed effects } & \multicolumn{2}{|c|}{ Year, Industry } & \multicolumn{2}{|c|}{ Year, Industry } & \multicolumn{2}{|c|}{ Year, Industry } \\
\hline & & & \multicolumn{4}{|c|}{$\begin{array}{l}\text { Comparison of coefficients on LowDisclosure: Test for } \\
\qquad(2)>(3) \text { Null hypothesis: }(2)=(3)\end{array}$} \\
\hline & & & & P-valu & & \\
\hline
\end{tabular}

This table presents results of R2Diff regressed on our variables of interest. R2Diff equals the incremental explanatory power of industry-level returns over market returns to explain variation in firm-level returns. We regress R2Diff on LowDisclosure, defined in Appendix A. We do this for the full sample in column 1, for the sample of firms that have a Rich Information Environment in column 2 (i.e. firms belonging to industries in which material ESG disclosure is above average) and for the sample of firms that have a Poor Information Environment in column 3 (i.e. firms in industries having below average material ESG disclosure). Below the Rich/Poor Information Environment specifications, we report the statistical significance of the differences in coefficient estimates for our variables of interest, based on a system of seemingly unrelated regressions that jointly estimates 
the models and takes into account correlations in residuals across the regressions (Zellner 1962). This procedure uses a common sample for the two regressions and allows to explicitly test whether the coefficients on the various independent variables are different across the two models.

Table 9

Other Sustainability Disclosure

\begin{tabular}{|c|c|c|c|c|}
\hline \multirow[b]{2}{*}{ Variable } & \multicolumn{2}{|c|}{$\begin{array}{c}\text { (1) } \\
\text { Dependent variable: } \\
\text { Synchronicity }\end{array}$} & \multicolumn{2}{|c|}{$\begin{array}{c}(2) \\
\text { Dependent variable: } \\
\text { Synchronicity }\end{array}$} \\
\hline & Coef. & $t$-stat & Coef. & $t$-stat \\
\hline OtherSustDisc & 0.0181 & 0.10 & -0.0806 & -0.44 \\
\hline SustReport & & & -0.0372 & -0.82 \\
\hline MaterialDisc & & & -0.4846 & -3.76 \\
\hline MarketCap & 0.3470 & 27.70 & 0.3832 & 23.36 \\
\hline InstOwn & 0.6268 & 7.05 & 0.5911 & 6.86 \\
\hline AnalystRev & -0.0090 & -0.83 & -0.0067 & -0.62 \\
\hline MTB & 0.0017 & 0.84 & 0.0015 & 0.78 \\
\hline StdDevROA & -0.9980 & -3.81 & -0.9721 & -3.79 \\
\hline InsiderTrades & -0.1005 & -2.01 & -0.1156 & -2.33 \\
\hline Intercept & -8.1716 & 26.42 & -8.7228 & -24.06 \\
\hline$N$ & \multicolumn{2}{|c|}{10,407} & \multicolumn{2}{|c|}{10,407} \\
\hline Adjusted- $R^{2}$ & \multicolumn{2}{|c|}{0.565} & \multicolumn{2}{|c|}{0.568} \\
\hline Fixed effects & \multicolumn{2}{|c|}{ Year, Industry } & \multicolumn{2}{|c|}{ Year, Industry } \\
\hline
\end{tabular}

This table presents robustness results of stock return synchronicity regressed on both material sustainability disclosure and other (non-material) sustainability disclosure, and other control variables. All variables are winsorized at the 1- and 99-percent levels, and defined in Appendix A. Regressions include year and industry fixed effects, with standard errors clustered by firm. 
Table 10

Synchronicity Measure Validity

\begin{tabular}{|c|c|c|c|c|c|c|}
\hline \multirow[b]{2}{*}{ Variable } & \multicolumn{2}{|c|}{$\begin{array}{c}(1) \\
\text { Dependent variable: } \\
\text { Synchronicity }\end{array}$} & \multicolumn{2}{|c|}{$\begin{array}{c}(2) \\
\text { Dependent variable: } \\
\text { Synchronicity }\end{array}$} & \multicolumn{2}{|c|}{$\begin{array}{c}(3) \\
\text { Dependent variable: } \\
\text { Synchronicity }\end{array}$} \\
\hline & Coef. & $t$-stat & Coef. & $t$-stat & Coef. & $t$-stat \\
\hline MaterialDisc & -0.6844 & -5.56 & -0.7067 & -5.83 & -0.5904 & -4.93 \\
\hline MarketBeta & 0.3869 & 9.50 & & & 0.5490 & 11.11 \\
\hline IndustryBeta & & & 0.4261 & 10.45 & 0.6250 & 11.36 \\
\hline SustReport & -0.0822 & -1.71 & -0.0741 & -1.66 & -0.0632 & -1.42 \\
\hline MarketCap & 0.4020 & 23.40 & 0.3486 & 21.58 & 0.3710 & 22.18 \\
\hline InstOwn & 0.5249 & 6.04 & -0.0184 & -1.6 & -0.0242 & -2.11 \\
\hline AnalystRev & -0.0057 & -0.48 & 0.0019 & 0.83 & 0.0018 & 0.84 \\
\hline MTB & 0.0029 & 1.33 & -1.0272 & -3.67 & -1.2059 & -4.40 \\
\hline StdDevROA & -1.0546 & -3.91 & 0.5171 & 5.97 & 0.5034 & 5.95 \\
\hline InsiderTrades & -0.2119 & -4.00 & -0.1953 & -3.68 & -0.1855 & -3.59 \\
\hline Intercept & -9.5326 & -23.48 & -8.1254 & -22.94 & -9.0535 & -23.15 \\
\hline$N$ & 10,407 & & 10,40 & & 10,4 & \\
\hline Adjusted- $R^{2}$ & 0.421 & & 0.41 & & 0.4 & \\
\hline Fixed effects & Year, Indus & & Year, Ind & stry & Year, In & stry \\
\hline
\end{tabular}

This table presents robustness results of stock return synchronicity regressed on material sustainability disclosure and other control variables. We control for the market and industry betas in our regression model. All variables are winsorized at the 1- and 99-percent levels, and defined in Appendix A. Regressions include year and industry fixed effects, with standard errors clustered by firm. 